\title{
Experimental Investigation on Replacement of Cement in Concrete Partially by using Dolamite Powder
}

\author{
Pramod Dhamne1, Dr. P. B. Nagarnaik ${ }^{2}$ \\ 1P.G. Students, 2 Professor \\ 1,2Department of Civil Engineering, G. H. Raisoni College of Engineering \& Management Wagholi, \\ Pune, Maharashtra, India \\ An Autonomous Institute Under UGC Act 1956 \& Affiliated to Savitribai Phule Pune University
}

\begin{abstract}
How to cite this paper: Pramod Dhamne | Dr. P. B. Nagarnaik "Experimental Investigation on Replacement of Cement in Concrete Partially by using Dolamite Powder" Published in International Journal of Trend in Scientific Research and Development (ijtsrd),

ISSN: 2456-6470,

Volume-3 | Issue-3, April 2019, pp.790-

792, URL:

https://www.ijtsrd.c

om/papers/ijtsrd23

035.pdf

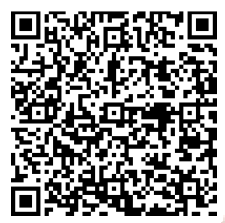

IITSRD23035

Copyright (C) 2019 by author(s) and International Journal of Trend in Scientific Research and Development Journal. This is an Open Access article distributed under the terms of the Creative Commons

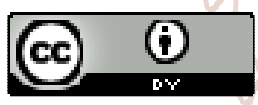
Attribution License (CC BY 4.0) (http://creativecommons.org/licenses/ by $/ 4.0$ )
\end{abstract}

\section{INTRODUCTION}

Cement is one of the foremost ingredient of concrete, since it is having a property that it binds the aggregates and resists the atmospherical action. The producing process of cement is includes calcining argillaceous and calcareous materials at a high temperature. During conduction of this process, very large amount of $\mathrm{CO} 2$ has been releasing into the atmosphere. It is estimated that in the production of one ton of cement results the emission of 0.8 ton $\mathrm{CO} 2$. The various report use of replacement materials such as Dolamite powder, fly ash and limestone in Portland cement has much attention in recent years. The utilization of fly ash is one of the great \& most popular methods to reduce expansion of concrete because of alkali-silica reactivity. Dolomite is a carbonate material which is made up of calcium magnesium carbonate CaMg (CO3)2. Dolomite is rock forming mineral created attention for its exceptional wettability and dispersibility. Dolomite has higher weathering resistance. Dolomite is a preferred as construction material due to it's higher surface area, hardness and density. Dolomite used as a filler material due to its higher strength and hardness. By the effective utilization of dolomite powder as a construction material, the objective in reduction of construction cost can be acheived. An attempt was attained to explore the possibility of using dolomite as a replacement material for cement M30 grade concrete and its specimens were made by replacing 0 , $5,10 \& 20 \%$ of cement by dolomite powder. The Compressive, Split tensile and Flexural strength of the specimens were found on the 7th and 28th days. Optimal replacement percentage of dolomite was determined.

\section{Liturature Review}

\subsection{Author: Shanu Sharma}

Author studied use of cement and production of cement produces much more issues of environment and also it is costlier process. Hence Marble Dust Powder can used as a developing binding material which will allow the concrete industry to optimize waste material use, reduce construction cost and construction of structures will be strong, durable and sensitive to the environment. The MDP was replaced with cement $0 \%, 7 \%, 14 \%, \& 21 \%$ by weight for M25 grade concrete. Flexural \& compressive strength Test are Conducted. The results achieved from this existing study shows that MDP has great potential for utilisation in concrete as an replacement of cement. 


\subsection{Authors: Preethi}

Author done experimental study on possibility of use of dolomite powder as an partial replacement material to cement. The some partial replacement percentages in experimental study were $0 \%, 5 \%, 10 \%, 15 \%, \& 20 \%$ by weight of cement. The compressive, split tensile \& flexural strengths of M20 concrete was conducted with dolomite powder were compared with those of reference specimens. It is found use of replacement of cement with dolomite powder to improve the strength of concrete is successful.

\section{Methodology \& Mix Design Material}

Cement: Ambuja Fifty Three grade cement which is confirming to IS 12269: 2013 used throughout the work. The cement used were fresh, lump free \& dry. All possible external content was uncontaminated while storing cement. Some properties of cement was found which are shown in following table I.

TABLE I

\begin{tabular}{|l|l|}
\hline Physical properties of cement Properties & Results \\
\hline
\end{tabular}

\begin{tabular}{|c|c|}
\hline Fineness & $7 \%$ \\
\hline Specific gravity & 3.16 \\
\hline Initial setting & $150 \mathrm{~min}$. \\
\hline Final setting & $270 \mathrm{~min}$. \\
\hline
\end{tabular}

\section{Fine Aggregate:}

The most important property of fine aggregate is to assist in producing workability and uniformity in the concrete mixture. The fine aggregate is also allows the cement paste to hold and binding coarse aggregate particle in suspension. This action promotes plasticity in the whole mixture and prevents the possible segregation of paste and coarse aggregate. It should be durable, clean and be free from organic matters. River sand were used as an fine aggregate. The specific gravity of sand is found to be 2.56 .

\section{Coarse Aggregate:}

The coarse aggregate is largest ingredient of concrete. In the presence of coarse aggregate in concrete reduces the drying, shrinkage and other dimensional changes occurring on account of movement of moisture. In this hard broken stone used as coarse aggregate in concrete. Here Size of coarse aggregate used in the Experiment was $20 \mathrm{~mm}$. The specific gravity of the coarse aggregate found to be 2.68 .

Table II

\begin{tabular}{|c|c|c|}
\hline Properties & Coarse Aggregate & Fine Aggregate \\
\hline Specific gravity & 2.67 & 2.70 \\
\hline Bulk density & $1558.5 \mathrm{~kg} / \mathrm{m} 3$ & $1632.9 \mathrm{~kg} / \mathrm{m} 3$ \\
\hline
\end{tabular}

Dolomite: Dolomite is a carbonaceous or carbonate material which is composed of calcium magnesium. Carbonate $\mathrm{CaMg}$ $\left(\mathrm{CO}_{3}\right)_{2}$. The term carbonate itself used to describe the sedimentary carbonate rock Dolostone (Dolomite Rock) it is composed predominantly of mineral dolomite with stoichiometric ratio of $50 \%$ or greater content of magnesium replacing calcium, often as a result of digenesis. Dolomite is a rock forming mineral which is noted for remarkable Wettability and dispersibility as well as moderate oil and plasticizers absorption.

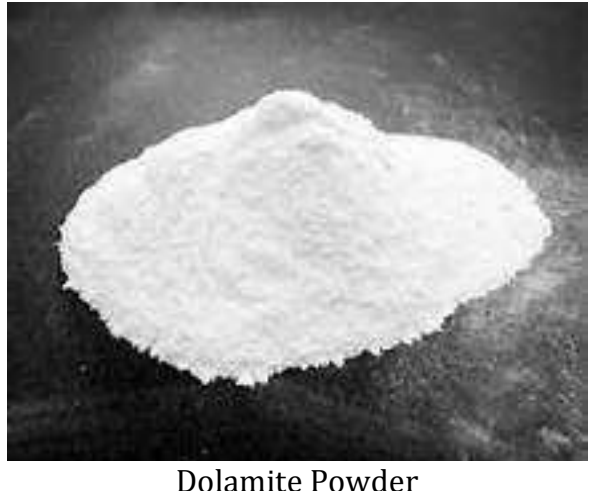

Table III

\begin{tabular}{|c|c|c|}
\hline S. No & Property & Dolomite Powder \\
\hline 1. & Formula & CaMg(CO3) 2. \\
\hline 2. & Sp. Gravity & 2.85 \\
\hline 3. & Color. & White, Off White \\
\hline 4. & Tenacity & Brittle \\
\hline 5. & Mosisture contant $(\%)$ & Nil \\
\hline 6. & Crystal system & Trignal \\
\hline
\end{tabular}

Water:

Water is an important ingredient in concrete as it is actively participates in the chemical reaction along with cement. The water which is used for making concrete should be clean and free from impurities like organics, oil, alkalis, acids etc.

Water which was used for making concrete should have a $\mathrm{pH}$ between 6 to 8 . Locally available drinking water used in this work.

\section{Details of Concrete Mix:}

Grade of concrete is Selected as M30 and the mix design were done as per IS: 10262 - 2009 \& IS: 456-2000 for different percentage of dolomite powder replacing cement partially. Mixture is prepared at room temperature. Test specimens of prescribed mix designs are prepared and allowed to cure in water for 7 and 28 day at room temperature. Finally, tests are conducted for Compressive Strength, Split Tensile Strength on $7^{\text {th }}$ and $28^{\text {th }}$ day respectively.

Four concrete mixes was designated as Mix-1(Control Mix), Mix-2(5\% Dolomite), Mix-3(10\% Dolomite), Mix-4(20\% Dolomite).

\section{Details of Experimental Study}

1. Compressive Strength Test:

For this experiment $150 \mathrm{~mm} \times 150 \mathrm{~mm} \times 150 \mathrm{~mm}$ cubes of concrete were casting using M30 grade of concrete. Specimens made with ordinary Portland cement (OPC) and it was replaced with dolomite powder at $5 \%, 10 \%$, and $20 \%$, levels were casting was done. After 24 hours specimens were removed from mould and they are placed for water curing for 7 and 28 days. After curing, the specimens tested for compressive strength using compression testing machine.

\section{Split Tensile Strength Test:}

The tensile strength of concrete is one of basic and important property of the concrete. The split tensile strength test was conducted on concrete cylinder is method for determining the tensile strength of concrete. The split Tensile strength is tested on cylinders at different 
percentage of dolamite powder Content in concrete. The strength of concrete has been tested on cylinder at 7 days and 28 days curing 7 days test has been conducted to check the gain in initial strength of concrete 28 days test gives the data relating to final strength of concrete at 28 days curing. It is found and can be seen that dolamite powder improves the compressive and split tensile strengths of concrete. As the percentage of replacement of cement partially with dolamite powder increases the compressive \& split tensile strengths increases.

\section{Results}

1. Compressive Strength of Concrete

\section{Table IV}

\begin{tabular}{|c|c|c|}
\hline Mix & $\begin{array}{c}\text { Compressive } \\
\text { Strength } \\
\text { (7DAYS)(N/mm²) }\end{array}$ & $\begin{array}{c}\text { Compressive } \\
\text { Strength (28 DAYS) } \\
\left(\mathrm{N} / \mathrm{mm}^{2} \text { ) }\right.\end{array}$ \\
\hline Mix 1 & 17.11 & 28.48 \\
\hline Mix 2 & 23.53 & 42.51 \\
\hline Mix 3 & 27.10 & 46.37 \\
\hline Mix 4 & 26.33 & 38.27 \\
\hline
\end{tabular}

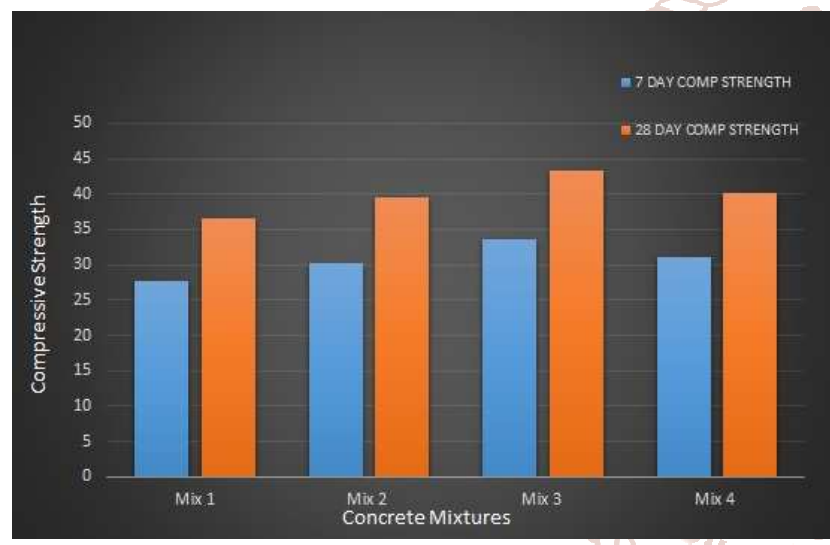

Chart1.Compressive Strength of Concrete at 7 th \& 28th Days

\section{Split Tensile Strength of Concrete:}

The split tensile strength of concrete was determined from Cylindrical Specimen of diameter $150 \mathrm{~mm}$ and height 300 $\mathrm{mm}$.

Table V

\begin{tabular}{|c|c|c|}
\hline Mix & 7 Days (N/mm2) & 28 Days (N/mm2) \\
\hline Mix 1 & 2.38 & 3.20 \\
\hline Mix 2 & 2.46 & 3.28 \\
\hline Mix 3 & 2.63 & 3.51 \\
\hline Mix 4 & 2.42 & 3.40 \\
\hline
\end{tabular}

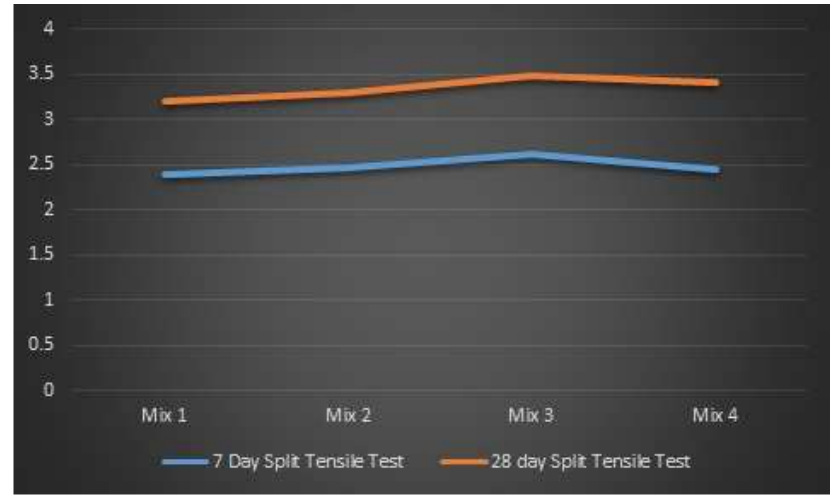

Chart2. Split tensile Test at 7th \& 28th day

\section{Conclusion}

The Compressive strength of Cubes are increased with addition of dolomite powder up to $10 \%$ replaced by weight of cement \& further any addition of dolomite powder the compressive strength decreases. The Split Tensile strength of Cylinders are increased in the addition of dolomite powder up to $10 \%$ replaced partially by weight of cement and further any addition of dolomite powder resulted the Split Tensile strength decreases. We have been found out the optimum replacement percentage of dolomite powder with cement and it is $10 \%$ of cement for both cubes and cylinders. We have put forth a simple step to minimize the costs for construction with usage of dolomite powder which is much more cheaply available. We have also stepped in into a realm the environmental pollution by cement production \& make use of cheaper material to get required quality of construction it has been our main objective as a Civil Engineers.

\section{References}

[1]. Shaikh Mohtasim M.A "Replacement Of Cement With Dolomite" International Journal On Modern Trends In Engineering \& Reserch, ISSN (0):2349-9745, ISSN(P):2393-8161

[2]. K. Sathishkumar, K. Anitha "Experimental investigation on partial replacement of cement by dolomite and fine aggregate by copper slag" International Journal of Pure and Applied Mathematics. Volume 116 No.14. 2017, 2530.

[3]. Shanu Sharma; "Experimental Investigation on Partial Replacement of Cement with Marble Dust Powder on Properties of Concrete"; International Journal of Software \& Hardware Research in Engineering; ISSN2347-4890;Volume 5 Issue 9 September, 2017

[4]. Er. Amritpal Kaur; "Strength and Duriabilty Properties of Concrete with Partial Replacement of Cement with Metakaolin and Marble Dust"; International Journal of Engineering Research \& Technology (IJERT) ISSN: 22780181; Vol. 4 Issue 07; July-2015

[5]. Prof. P. A. Shirule; "Partial Replacement of Cement with Marble Dust Powder"; International Journal of Advanced Engineering Research and Studies; E-ISSN2249-8974.

[6]. J. Satheesh Kumar, "Physical and Chemical characteristics of Dolomite for Partial Replacement of Cement in M20 Concrete"; Engineering \& Technology in India; Vol. 1:5 December 2016 